\title{
LEST WE FORGET THAT INDUSTRIAL AND ORGANIZATIONAL PSYCHOLOGY IS PSYCHOLOGY*
}

\author{
DJW STRÜMPFER \\ deostr@mweb.co.za \\ Departments of Psychology \\ Universities of Johannesburg and Pretoria
}

\begin{abstract}
The tie between industrial/organizational psychology (IOP) and general psychology should be taken seriously. The origin of the split into separate academic departments is discussed. Four IOP topics are presented which are rooted in psychology or where the psychological quality is strong, making the tie-in clear: motivation, leadership, assessment, and appreciative inquiry; by way of illustration, proponents are referred to. Specialization and professionalization often bring undue emphasis on technology. IOP cannot be human resource management. Suggestions are made about bringing IOP and psychology closer within teaching programmes and internships. Appreciative images of what IOP, hand-in-hand with psychology, could be like, are put forward.
\end{abstract}

Then join hand in hand ...

By uniting we stand, by dividing we fall.

- John Dickinson (1732-1808); Partington, 1992, p. 245)

Key words

Appreciative inquiry, assessment, cross-teaching, human relations movement, human resources managment, internship, leadership, motivation, scientific management.

* Revision of a paper presented at the Annual Conference, Society for Industrial and Organizational Psychology of South Africa, Pretoria, 09 June 2005

This article is dedicated to Prof. C.F. Schoeman who first taught me Industrial Psychology; thank you, Schoek, for over half-acentury of warm collegiality and friendship. My sincerest appreciation goes to Rita Kellerman for her incisive comments on drafts of this article; Jonathan Cook, Freddie Crous, and Conrad Schmidt also commented: I thank them cordially. Requests for copies should be addressed to D.J.W. Strümpfer, 1 Sabie Road, Emmarentia, 2195 - Johannesburg.

Industrial and organizational psychology (IOP) is psychology. If it is not psychology, what is it? Does it have a separate existence, or a right to separate existence? No, IOP is general psychology applied in industry and organizations. In the UK it is called occupational psychology, referring to it being applied to occupations. In Europe it is known as work and organization psychology. In terms of linguistics, using "psychology" modified by any of these extensions clearly indicates that "psychology" comes first and that the extensions indicate subdisciplines, which still remain part of psychology.

Yet, there is an opinion that is still favored in some IOP departments, which was expressed in a Senate meeting at the University of Port Elizabeth in the late 1960s by Prof. Izak van Biljon of Stellenbosch: "Mnr. die Rektor, bedryfsielkunde is nie sielkunde nie" (Mr. Rector, industrial psychology is not psychology). Out of conscious conviction, but I fear, sometimes out of political (small p) considerations, a chasm is maintained between IOP and its parent discipline of psychology. This paper is a plea to reverse this tendency as much as possible.

As a starting point, it is appropriate to ask what "psychology" is. I consider the core discipline, usually referred to as "general" psychology, to include such interdependent areas as developmental, personality, cognitive, physiological, and social psychology, as well as the study of various approaches to methodology. In addition to IOP, there are several applied areas, or domains of practice, among which clinical psychology has gained a somewhat distorting ascendancy.

\section{HOW DID THE SEPARATION COME ABOUT?}

Locating IOP in an entirely separate academic department, with no ties to the general psychology one, is an administrative arrangement unique to South African universities. How did this come about? What was/is involved? Both sides of the divide were, and still are, guilty of the separation.

Firstly, there were/are cocks who wanted/want to crow on their own dunghills. It is a matter of territoriality, power, and status. It is much more prestigious to be head of one's own department than, say, coordinator of a sub-department. If there were to be a democratic election, a psychologist usually would stand a better chance to be elected to the chair, since "psychology" is always the larger portion. Pure leadership struggles and small-group psychology are involved. Secondly, there are struggles, if not battles, about scarce resources. Generally, it is just more pleasant and prestigious to have separate buildings, a separate office for each head, separate teaching facilities, staff that need not be shared, separately owned equipment, a separate budget, and so on

\section{FOUR ILLUSTRATIVE TOPICS}

A practical matter is that there are areas of IOP that are inextricably part of psychology. There is nothing about these areas that marks them as uniquely industrial or organizational. It would be sad not to acknowledge the essential unity that exists-the Gestalt. By keeping it in mind, both areas are strengthened because this is a two-way street.

I shall illustrate by means of four diverse topics which are commonly assumed to be part of IOP, where either the roots are in psychology, or where the essential psychological quality is so strong that it is clear that the two sides should hold hands, namely, motivation, leadership, assessment, and appreciative inquiry. There are also other, partially emergent areas that will still be with us for a long time and deserve serious investigation, for example, computerization, robotization, and other technological ways in which work has been changed and will continue to do so; and then globalization, not just of the economy, but in the widest anthropological, sociological, and social-psychological senses too.

\section{Motivation}

Motivation is much broader than just work motivation. By reducing it to the latter, important theoretical and applied areas become excluded. Historically, Maslow, McGregor, Herzberg, Schein, McClelland, and others were, in the first place, psychologists who happened to devote part of their scientific 
energies to aspects of motivation in the world of work. Indicative of a revival of interest in the area is that both the Harvard Business Review (2003, January) and the Academy of Management Review $(2004,29$, No. 3) recently dedicated special topic forums to work motivation theory; another indication was that the Annual Review of Psychology, for the first time in 22 years, published a chapter on work motivation (Latham \& Pinder, 2005).

Scientific Management. Staying with the world of work for the moment, I want to start with a negative example: Why did Scientific Management, fail?

Coming from an industrial engineering background, Taylor (1911), along with many of his associates, focused his attention on the inefficiencies of factory production in an increasingly industrialized age. [They] proposed a new and paternalistic approach to managing workers that relied on a combination of job training, pay-for-performance incentive systems, improved employee selection techniques, and job redesign, including the introduction of ergonomics.... However, the subsequent rise of an increasingly sophisticated workforce, coupled with company efforts to maximize productivity without simultaneously increasing employee rewards, eventually served to discredit this system, leading to the widespread rise of unionization efforts in the 1930s. (Steers, Mowday \& Shapiro, 2004, p. 380)

The Gilbreths' time and motion studies approach should also be remembered here.

My point is that Scientific Management overemphasized the material and mechanistic sides of production, whilst ignoring the humanity of workers, particularly the personal and social psychological dimensions of their existence. A consequence was that when workers found opportunities to rebel against such management, they took them.

Human Relations Movement. Subsequently, a positive revision of philosophy was the Human Relations movement after World War I, although it did not overthrow scientific management (Collins, 2000). It resulted to a large extent from Mayo's studies at the Western Electric Company's Hawthorne Works in Cicero, Illinois. Elton Mayo (1880-1949) was an Australian-born psychologist. Most undergraduate students in IOP know about the Hawthorne Effect. Less attention is paid to the findings that incentive plans failed because they ignored group acceptance, group pressure, and group security (Robbins, 2001)-particularly the power of informal groups. "The single most important discovery of the Hawthorne experiments was that workers had a strong need to cooperate and communicate with fellow workers" (Reshef, 2003, 16; emphasis in original).

Awareness of Individuals. Increasingly, there also came a shift in awareness of the employee as an individual, including contributions to alleviate alienation at work. I shall mention a few psychologists who made significant contributions to such developments through their work on motivation, and whose work is often considered to be essentially IOP.

- Abraham Maslow (1908-70) was one of the fathers of humanistic psychology; yet, every IOP student knows about his (1954) hierarchy of needs, "one of the most widely recognized theories of motivation" (Robbins, 2001, p. 589). In terms of self-actualization, he argued that workers were alienated because their work did not permit them to use their capacities and skills in a mature and productive way.

- Douglas McGregor (1906-70) was a social psychologist who later in his career was a professor of management at MIT. (If anyone doubts his credentials as a psychologist, his Ph.D. dissertation was on: The sensitivity of the eye to the saturation of colors.) His Theories X and Y are stock in trade of IOP, and his The human side of enterprise (McGregor, 1960) still makes good reading. (Business Library Staff, no date)

- Frederick Herzberg (1923-2000) was trained as a clinical psychologist, did much of his motivation research while he was professor of psychology at Western Reserve University, although he later became professor of management at Utah University. His "overriding interest in mental health" stemmed from his belief that it "is the core issue of our times", which was prompted by his posting to the Dachau concentration camp after its liberation (The Management Thinkers, no date). In IOP, he is known as the father of job enrichment and the originator of the motivation-hygiene theory (Herzberg, Mausner \& Snyderman, 1959, 1968). Robbins was of the opinion that, "With the possible exception of the Hawthorne studies, no single stream of research has had a greater impact on undermining the recommendations of scientific management than the work of Frederick Herzberg" (2001, p. 591).

- Edgar Schein (b. 1928) also did a Ph.D. in clinical psychology and served an internship in the US Army Clinical Psychology Program; he had a strong interest in social psychology too. Serving for several years at a military neuropsychiatry research institute, he did extensive research on returning prisoners of war, which brought him wide recognition. Subsequently, McGregor invited him to MIT, where his interest in organizational psychology blossomed - a concept he coined. He made important contributions to process consultation, and he is credited with inventing the term "corporate culture", about which he wrote extensively. (Schein, 1969, 1980, 1985, 1993; Thinkers 50, 2003)

- David McClelland (1917-98) obtained a Ph.D. in experimental psychology and he held positions in psychology all of his academic life. His work on the achievement and power motives brought him fame but he also contributed to knowledge of the entrepreneurial spirit in general, as well as job competencies. (McClelland, 1961, 1975, 1985; McClelland \& Winter, 1969; McGraw-Hill/Dushkin, no date)

- Julian Rotter (1923-85) was a clinical psychologist and his main contribution was in terms of social learning theory in that sub-discipline. I am listing him here in view of the local interest deepened by Schepers' (1995) development of a widely used Locus of Control Inventory. Rotter's (1966) concept of generalized expectancies for control of reinforcement, commonly known as "locus of control", refers to people's very general, cross-situational beliefs about what determines whether or not they get reinforced in life. It has important implications for IOP too. (Mearns, 2004)

\section{Leadership}

Leadership is a second area in IOP where the roots grew in general psychology. Three significant examples will do.

- Rensis Likert (1903-81) obtained a Ph.D. in psychology (with a dissertation on, A technique for the measurement of attitudes). After teaching psychology for five years, he became director of research for the Life Insurance Agency Management Association in Hartford, CO, where he started a programme of research on the effectiveness of different styles of supervision. In 1946 he established the vastly important Institute for Social Research at the University of Michigan. In psychometrics, he is identified with "Likert scales". To IOP, his best known contribution was identification of an employee orientation and a production orientation in management (Likert, 1961). Subsequently, Likert (1967) proposed four styles of management leadership: Systems 1 to 4 , in this sequence known as exploitive autocratic, benevolent autocratic, participative, and democratic. With his wife, he also contributed on conflict management (Likert \& Likert, 1976). (Witzel, 2001b)

- Robert Blake (1918-2004) held a Ph.D. in psychology. With Jane Mouton, he developed the Managerial Grid theory (Blake \& Mouton, 1964, 1968). Essentially based on the Ohio State University leadership studies, they identified two styles: concern for people and concern for production; by representing these on a $9 \times 9$ grid, they defined five "pure" styles and potentially 81 positions. They developed a structured Grid Seminar that was presented thousands of times world wide, including in South Africa. More recently they developed the much more complex SYMLOG model, of which the Grid takes up just one quadrant (Blake \& Mouton, 
no date). They also applied their insights to salesmanship (Blake \& Mouton, 1970) and to solving organizational conflicts (Blake \& Mouton, 1984). Blake was a prominent figure in NTL organizational development too. (Grid International, 2004)

- Fred Fiedler (b. 1927) obtained a Ph.D. in clinical psychology (with a dissertation entitled, $A$ comparative investigation of the therapeutic relationships created by experts and non-experts of the psychoanalytic, non-directive, and Adlerian schools, a study which clinical psychologists would still recognize). From the late 1960s through the 1980s, leadership interests turned to contingency models and Fiedler's model of leadership effectiveness was one of the earliest and best known. Whilst his predecessors assumed that there was one best style of leadership, Fiedler's (1967) model postulated that the leader's effectiveness is based on "situational contingency", or a match between the leader's style and situational favorableness. (Witzel, 2001a)

\section{Assessment}

"Assessment" is clearly a concept and an activity that bridges psychology and IOP. However, its roots cannot be claimed by the latter. According to Cronbach (1960), assessment originated in German military testing in the early 1930s, using leaderless group discussions, as well as other tasks performed by pairs or small groups of men. Complex behaviour and "character" were observed for selection purposes, involving intellect, emotions, and habits of cooperation, dominance, and taking initiative. British War Office Selection Boards followed suit during wartime conditions, to select officers from the ranks (cf. Cronbach, 1960, p. 581).

Henry Murray (1893-1988), with an M.D. and a Ph.D. in Biochemistry, became a psychologist via Jung. He became director of the Harvard Psychological Clinic and eventually professor of clinical psychology there (Hall, Lindzey \& Campbell, 1998). With a large group of post-graduate students, he initiated a programme of "personology" research, using multiple techniques, including extensive observations in unstructured situations, and afterwards dynamic integration of findings in conferences of experienced psychologists. The outcome was an influential volume that described their methodology and a comprehensive classification of personal needs and environmental press (Murray et al., 1938/1962). In 1943, Murray established and directed an assessment service for the US Office of Strategic Services (OSS; Office of Strategic Services Assessment Staff, 1948). During World War II this service developed a programme to select persons for irregular, secret, and hazardous missions, such as espionage and counterespionage, and leading resistance groups behind enemy lines. Unusual and complex abilities and dispositions were called for, such as independence of judgment, adaptive flexibility, willingness to assume individual responsibility, loyalty, and leadership in general. Hence an holistic approach was developed to study personality as an organized whole, and particularly to assess positive aspects. Naturalistic, situational, or performancesimulation settings were devised for extended observations. The term assessment originated in this seminal venture, to distinguish it from psychometrics.

The Institute of Personality Assessment and Research was established at Berkeley in 1949. Its director was Donald MacKinnon, who had been a member of the OSS staff. The OSS assessment approach was continued, and from it came a great deal of research, especially on persons "nominated by experts for their outstanding qualities of originality, personal soundness, creativity" (MacKinnon, 1978, p. 9). The US Veterans Administration also used the assessment approach in an extensive study of clinical psychologists in the late 1940s, early 1950 s.

An associate of Murray, Douglas Bray (with a Ph.D. in psychology), designed and applied the first management assessment centre at the American Telephone and Telegraph Company in 1956 (Bray \& Grant, 1966; DDI, no date), but it would appear that others were also experimenting with this approach in other business and industrial settings around that time. It eventually became an approach used by countless company, military, and other assessment programmes.

\section{Appreciative Inquiry}

Appreciative inquiry (AI) fits well with fortology (or positive psychology; Strümpfer, 2006), as part of positive organizational scholarship (Cameron, Dutton \& Quinn, 2003; also see http://www.bus.umich.edu/Positive/). It is prominently used in organizational development but it is equally popular with community psychology, social work, and other sub-disciplines. As far as psychology and IOP are concerned, AI is taking its position in a long tradition of a strengths paradigm to which psychologists and psychiatrists like James, Jung, Allport, Murray, Rogers, Frankl, and Maslow have all contributed, but which started blossoming forth during the late 1970s and 80s, really to flourish since 2000 (Strümpfer, 2005). It is clearly a "non-sectarian" philosophy and methodology, with a tap root in psychology but other roots in related disciplines too.

The central idea is to create appreciative, affirmative images in people's minds. The concept of the image in this context is not new; Kenneth Boulding wrote a book, The image, around the proposition that the current behaviour of a person or an organization is determined by the image, or the subjective knowledge, or what the person or organization believes to be true (1956/1987, cf. pp. 6, 115). James Ludema (2001; also see Ludema, Wilmot \& Srivastva, 1997) provided an excellent introduction to AI, entitled, "From deficit discourse to vocabularies of hope: The power of appreciation". David Cooperrider was the originator, with his doctoral supervisor, Suresh Srivastva, as his original supporter.

There is a neologism from North America, blamestorming: sitting around in a group, discussing why a deadline was missed or a project failed, and who was responsible. This is what can, and often does, happen in organizational development. However, instead of asking the typical questions about what was wrong with an organization, Cooperrider decided on an approach of searching for strengths. Cooperrider and Sekerka described AI as examining "what contributes to the best of organizational life as a starting point for change", and as "a process of search and discovery designed to value, prize, and honor" (2003, pp. 225 , 226) in human groups and organizations. Cooperrider (2001; also see Cooperrider \& Whitney, 2003; Cooperrider, Barrett \& Srivastva, 1995) built on findings from neuro-psychology, which give psychological phenomena a causal role in brain processing, as well as social constructivism, which poses that humans create their own realities through symbolic processes. Writing about his own experiences with AI, Bushe wrote:

I have found that an appreciative inquiry, where people listen to each other's stories about micro moments in organizational life where the best in us is touched, can create a unique climate for collective dreaming where the forces of ridicule and repression are momentarily suspended. There is something about telling one's story of "peak" organizational experiences, and listening to others, that can make a group ready to be open about deeply held desires and yearnings (2001, Section: Socially Constructing Reality, 3; emphasis in original).

Bushe also provided the following example:

Recently I had a group of Executive-MBA students use appreciative process to create a change in any social system they chose. We were all blown away by the results. For example, one manager's "problem person" became his star employee when he looked for examples of her being a star. Another manager's conflicted and competitive team became a cohesive, cooperative unit when he looked for examples of 
cohesion and cooperation. Those using it with spouses or children felt that major positive transformations had occurred in their families.

Two local examples can be found in Fourie, Woods and Bluen (2005), and Van Vuuren and Crous (2005).

\section{IOP AND HUMAN RESOURCE MANAGEMENT}

IOP is not human resource management (HRM) and cannot be turned into it. By analogy, this is so, just as physics is not engineering and physiology is not internal medicine. In all three cases, the first mentioned discipline is basic to the second-mentioned, but in all three cases the second one mentioned also has other disciplines reaching into it. In addition, in all three cases, the second one mentioned is clearly an applied discipline.

\section{Scientific and Applied Disciplines - or Mixes}

Psychology is a curious mixture of basic and applied science. Even though some of its sub-disciplines have developed vast applications, at its core psychology is basic science. To become a psychologist there is extensive theoretical material to be covered as a prerequisite to becoming involved in whatever application; and even the applied fields have extensive theory of their own to be mastered.

A development that stands in need of serious rethinking is, nevertheless, that specialization and, particularly, professionalization, often introduce a narrowness of vision, as well as an undue emphasis on applied technology. Technologies can evolve to the point where they stand alone, can be taught, and then practised as such, without further critical analysis or evidence. Since practice is a source of income, the technologies could find their way back into the teaching of the original disciplines. This is frequently seen as a logical process, since students are, after all, taught so that they can eventually go out and make a living. The next step is also logical, that those who teach should be experienced in these technologies too

It also worries me that such technologies are so often fads that come and go. Particularly, management fads tend to come in loud, short-run bursts, marketed exceptionally well by the book and magazine trade, because the competition is so hectic - the next one is constantly in the making. Although they have since been named as starting a fad themselves, Hammer and Champy (1993, p. 25) provided a long list of examples, e.g. Theory Z, quality circles, excellence, and one-minute managing. Like the old sailor's get-up-and-go, former fads got up and went. From my conservational point of view, a problem with such fads is that they tend to be somewhat evangelical, contradictory, and without overly much theory and research behind them (Collins, 2000). Denrell has, for instance, illustrated how selection bias in studying only successful, or even only highly successful companies, but no ailing or failed ones - a common methodology of management gurus in preparing proposals for benchmarking - is "the classic statistical trap" $(2005$, p. 114 ; in epidemiology it is known as the "healthy worker effect"). Yet, their advice and their inadequate data could readily be imported into the teaching of IOP to provide currency, displacing more solid material in the process.

There is a danger of dilution of the syllabi of basic disciplines, since only so much can possibly be covered in the available time - and some things then have to make room for the imports. The process starts at the undergraduate level and there are two sides to it. Firstly, students have an eye on their future and want to learn to do useful things. (At UCT a dean commented that students look for the word "industrial" on their diplomas, since that catches the eye of employers.) Secondly, having invested in becoming proficient at professional activities and usually enjoying these too, lecturers could easily spend a disproportionate amount of time on such aspects of the syllabus, at the expense of background material on theory and research, particularly when their students tend to demand such and enjoy the "real life stuff" more than "dry theory". (This epithet should, however, be laid squarely at the feet of uninspired teachers; most of us have experienced the privilege of teachers who brought supposedly "dry" areas to vibrant life.)

Clearly, these are both/and, rather than either/or propositions. My fear is simply that it could go too far, and often has gone too far, often to the point where, for instance, it becomes hard to distinguish between university programmes and those of technical universities. The situation is going to get more problematic where universities and technikons have been merged, because there will be pressure not to differentiate. Will, for instance, a B.Com. programme remain separate from a B.Tech. programme when there is a shortage of teaching and other resources? These comments should not be interpreted as my being condemnatory about applications or technology - that would be inconceivably short-sighted. I am merely defending a particular territory.

Nature of HRM. At present, there are various routes into "HRM". Long ago military experience and the pastorate were accepted routes into personnel management. Then there are routes via Institute of Personnel Management or technikon diplomas; then the academic routes of a B.Com., B.A. (including industrial sociology), or B.A. (Social Work); then an Honours in psychology, IOP, or industrial sociology. For the higher ranks, there is M.Com. or M.A. in IOP, and sometimes an M.B.A., which is a relatively new route. Psychology should be listed because persons with clinical, counseling or research degrees often find a career in HRM. Such diversity clearly indicates that "HRM", in its traditional South African garb, is an hybrid multiformity, and perhaps ought better still be called by another name, like personnel practice, personnel management, or people management.

In Europe and in American business schools, HRM has, in the meantime, been turned into a management science, with theoretical inputs from diverse human, economic, and mathematical sciences. In fact, it has also turned into the kind of mixture of theoretical foundations and applications one sees in psychology (see e.g. several articles in Management Revue, 2005, 16, No. 2). It has become Strategic HRM, practised most clearly in the upper echelons of organizations. South Africa is not isolated in this respect. The route into it is usually fairly extensive general management experience, followed by an MBA or a master's degree in strategic HRM. A concern is that at present just a single, somewhat watered-down module in HRM is taught in many MBA programmes. Lower degrees in Psychology or IOP may provide a route in, but any human or economic science, information technology (IT), mathematics, engineering or law qualification seems appropriate too. It is a matter of specialization after a liberal education.

This kind of HRM has fewer foot soldiers than used to be traditional. Human resources administration and even some of training are rapidly disappearing into IT (e.g. SAP and computer assisted education). HR administration is increasingly being centralized, thus cutting costs. However, doing so is also strategic - it is a computerized extension.

Such developments have implications for IOP too. A higher degree in IOP is no longer an appropriate qualification for performing all tasks in the "new" HRM. It seems to me that at an advanced level IOP should become more of a basic science that provides part of the renewing theory and research which strategic HRM needs. Other management sciences, like strategy, finance, and marketing, similarly rely on basic sciences for renewing theory and research. The ideal relationship between a 
basic science and the disciplines where it is applied is that developments in basic science should constantly inspire and enable new development-wherever it is applied. An applied discipline should retain close ties with the fertile soil from which it blossoms forth.

\section{WHAT BOULDING HAD TO SAY}

Kenneth Boulding (1910-1993) was an economist, systems thinker, peace activist, and poet (Keyfitz, no date). Earlier on I referred to his concept of the image which determines the behaviour of a person or an organization. Writing about subcultures, for instance, academic disciplines and departments, he commented that the images grow, change, develop, and decay within the walls which the subcultures themselves have built. "Each ... follows its own line of development, often without much regard to what is happening in other disciplines, or even the world outside. Because lines of communication all turn inward, the members of a subculture devote themselves to the elaborate solution of problems which they themselves create" (1956/1987, p. 145). With lines of communication lying within, the image of each one tends to be self-perpetuating and selfsupporting. "A mutual admiration society is a fine way of persuading us that we are all fine fellows for nobody ever contradicts us" (p. 146). He described similar occurrences in professional subcultures.

There is a saying in the Bible: "He who has ears, let him hear" (Matthew 13: 43).

Boulding also expressed concern that "the universe of discourse is crumbling into a multiverse" (p. 139). However, he pointed to signs that give hope, in the form of interdisciplinary and interdepartmental communication, even an interdisciplinary movement in the form of cross-disciplinary institutes (e.g. the Harvard Social Relations Department) and newer disciplines, like cybernetics and management science; I want to add systems thinking and fortology (positive social science), as colligating or bonding paradigms, and project management as a model. What happens in such instances is that messages which are inconsistent with the images built up through past inward communications are received from other subcultures. When these are attended to and acted upon, the images held by all of them change, sometimes quite rapidly.

Systems thinking is an obvious solution to this kind of problem. A core element in our images of science - whichever one we as individuals identify ourselves with - should be a deep awareness that all scientific disciplines are in some way or other interconnected; they ought to be considered in constant synergistic interaction. Wilson called this "consilience, literally the 'jumping together' of knowledge by the linking of facts and fact-based theory across disciplines to create a common groundwork of explanation" (1998, p. 6). In a more humorous frame, "Muir's Law" states: "When we try to pick out anything by itself we find it hitched to everything else in the universe" (Bloch, 1980, p. 94). At a given time, one may be working at a mechanistically isolated problem, but one has to remain aware of the synergism, and gain from it wherever possible.

\section{WHAT CAN BE DONE?}

I want to return to my starting point: a plea to reverse the separation between IOP and psychology as much as possible.

In the first place, we have to listen for, and to, messages that come from next-door disciplines and sub-disciplines, as well as others further removed. Then, as an ongoing venture, we have to start rethinking our values, reconsider our priorities, but next do strategic planning, and finally, act according to our best insights.
It is probably too much of a dream to think that we would easily be able to merge IOP and psychology departments administratively. But perhaps there will be some authority, like a minister of education, who could by fiat accomplish a merger much smaller than the current mergers of universities and technikons. (Who would have thought ten years ago that such a thing was possible?) There could, nevertheless, be significant toenaderings (getting closer), keeping in mind "Clarke' Second Law" that: "The only way to discover the limits of the possible is to go beyond them into the impossible" (Bloch, 1977, p. 77).

"Toenadering" does not imply elimination of all boundaries around IOP, just as this cannot be done in connection with other applied fields. Perhaps one can find an analogy in osmosis through a semi-permeable membrane; some "thin" organizational boundaries should protect each of the domains of practice but these should be at their most permeable around the core areas of the parent discipline. In the case of IOP, there should be assurance that IO psychologists learn about the organizational context in which work is done and managed; additionally, they should become grounded in business/management disciplines too.

One "toenadering" would be cross-teaching. A well-trained clinical or counseling psychologist ought to have had a solid course in organizational psychology. It cannot be a simple repetition of an existing IOP module, because allowance has to be made for developing some introductory background. Perhaps it could be something akin to an MBA first course in organizational behaviour. But then all IO psychologists need a thorough introduction to psychopathology, taught by someone well-versed in it. In terms of my own interests, there ought also to be a course in psychofortology (Strümpfer, 2006; Wissing \& van Eeden, 1997), but that could as well be a broader personality course, or a course on adult development. They ought to get a similar background in counseling. There may well be courses that could be offered jointly on, e.g., group-dynamics and conflict solving, particularly if there were an experiential emphasis; parts of psychometrics and assessment could also be considered. Careful (and caring?) cross-consultation and planning could reveal other possibilities. Whilst some crossteaching should ideally happen at undergraduate level, it is particularly necessary at the Honours and coursework master's levels. Students of both applications typically hanker to know about what happens "on the other side of the fence".

Cross-teaching of courses should be, for instance, not by an IOP lecturer who has read a psychology textbook, but by persons with a well-rounded psychology orientation; the same applies to IO courses taught to psychology students. It requires an inspired and knowledgeable teacher to offer an unbiased course that provides a balance between IOP and clinical, counseling or community psychology. Team-teaching would, of course, be an excellent solution too. Teachers themselves are too often professionally one-sided and cannot see the forest for the trees - in fact, sometimes they do not even see the trees but are just leaf people. We can take world-renowned authors in psychometrics, like Anastasi (Anastasi \& Urbina, 1997) and Nunally (Nunnally \& Bernstein, 1994), as models who did not write "either/or" books.

Similar arguments could be raised about internships. Non-IO psychologists are all likely to have dealings with people in the world of work and organizations. They would benefit from a portion of their internships spent in a carefully chosen environment of that kind, with well-chosen activities, under proper supervision; they should not be viewed as persons to be tolerated until it is over. Similarly, IO psychologists could do with a placement in a clinic or a psychiatric hospital, where they can interact with patients, possibly doing some interviewing and testing (but not doing psychotherapy), and then attending case conferences - of course with the same provisos as those above with respect to supervision. 
There are serious arguments about time and load limitations. But might there not be areas that could be judiciously trimmed? In all programmes, there are things taught just because they have been taught "all these years", or because an important figure believes that that should be part of the syllabus, or because someone happens to be good at it or enjoys teaching it. For instance, is ergonomics really essential? How much statistics is essential in the light of statistical packages, how much information about labour legislation, how much personnel administration, or how much training skill? And so forth. Where there is a will, there is a way.

These are two solutions I could come up with. I am sure there are others too.

\section{IMAGERY}

In connection with AI, I wrote about the importance of images. I want to end my meandering path by sharing three appreciative images of what IOP, hand-in-hand with psychology, could be like. ${ }^{1}$

I want to call my first image "The Pensive Watcher". This image contains a pensive, contemplative quality, with caring for other people's feelings, perhaps even tinged with sadness. I once quoted Pope John Paul II saying in a prayer in 1979: "I watch"; afterwards he explained that it meant that, "I make an effort to be a person of conscience" (Strümpfer, 1993). This is a kind of thinking which women perhaps do more naturally than men but which all of us need to do constantly in working with people. In many contingencies such quiet contemplation is likely to have long-lasting consequences.

The second image I want to call "The Aroused Thinker". Here I have in mind a stronger, active, problem-solving kind of thinking. Perhaps there is a more typically masculine tendency here and possibly it comes more easily to men; but again, we all have to put our backs into it. As psychologists we struggle with deep-rooted problems that influence the lives of people, if not all humankind. Let us think as scientists, let the thinking become creative, but also generate tension and motivation to tackle those problems in ways that will bring about deeply significant things.

My third image of the disciplines of psychology flows from the first two: "The Bold Worker". It is an image of magnificent courage, relentless labour, and ceaseless struggle - characteristics we certainly need in our academic and professional activities.

Let us, as psychologists in general, and as IO psychologists in particular, contemplate with deep consideration for the human condition and be inspired towards caritas - loving kindness. Let us also be dynamic thinkers and creators. But lastly, let us be alive with courage and boldness, let us labour relentlessly, and struggle ceaselessly, to serve humankind both as scientists and as professionals.

\section{REFERENCES}

Anastasi, A. \& Urbina, S. (1997). Psychological testing (7th ed.). Upper Saddle River, NJ: Prentice-Hall.

Blake, R.R. \& Mouton, J.S. (1964). The Managerial Grid: Key orientations for achieving production through people. Houston, TX: Gulf Publishing.

Blake, R.R. \& Mouton, J.S. (1968). Corporate excellence through Grid® organization development. Houston, TX: Gulf Publishing.

Blake, R.R. \& Mouton, J.S. (1970). The grid for sales excellence: Benchmarks for effective salesmanship. New York: McGrawHill.

Blake, R.R. \& Mouton, J.S. (1984). Solving costly organizational conflicts. San Francisco: Jossey-Bass.
Blake, R.R. \& Mouton, J.S. (no date). SYMLOG and the Leadership Grid®. Retrieved 21 March 2005 from the World Wide Web: http://www.symlog.com/internet/how_symlog_relates/Lead ership_Grid.htm.

Bloch, A. (1977). Murphy's Law and other reasons why things go wrong! Los Angeles: Price/Stern/Sloan.

Bloch, A. (1980). Murphy's Law book two: More reasons why things go wrong! Los Angeles: Price/Stern/Sloan.

Boulding, K.E. (1987). The image: Knowledge in life and society. Ann Arbor: University of Michigan Press. (Original work published 1956)

Bray, D.W. \& Grant, D.L. (1966). The assessment center in the measurement of potential for business management. Psychological Monographs: General and Applied, 80 (Whole No. 625)

Bushe, G.R. (2001) Five theories of change embedded in appreciative inquiry. In D. Cooperrider, P. Sorenson, D. Whitney, \& T. Yeager, (Eds.), Appreciative inquiry: An emerging direction for organization development (pp. 99-109) Champaign, IL: Stipes. Retrieved 22 March 2005 from the World Wide Web: http://www.gervasebushe.ca/ai5.htm.

Business Library Staff (no date). Douglas McGregor (1906-1964). Richard Ivey School of Business, University of Western Ontario, London, Ont. Retrieved 20 March 2005 from the World Wide Web: http://www.lib.uwo.ca/business/ dougmcgregor.html.

Cameron, K.S., Dutton, J.E. \& Quinn, R.E. (Eds.) (2003). Positive organizational scholarship: Foundations of a new discipline. San Francisco: Berrett-Koehler.

Collins, D. (2000). Management fads and buzzwords: Criticalpractical perspectives. London: Routledge.

Cooperrider, D.L. (2001). Positive image, positive action: The affirmative basis of organizing. In D.L. Cooperrider P.F. Sorenson, T.F. Yaeger \& D. Whitney (Eds.), Appreciative inquiry: An emerging direction for organization development. Champaign IL: Stipes Publishing. Retrieved from the World Wide Web 19 February 2004: http://www.stipes.com.

Cooperrider, D., Barrett, F. \& Srivastva, S. (1995). Social construction and appreciative inquiry: A journey in organizational theory. In D. Hosking, H.P. Dachler \& K. Gergen (Eds.), Management and organization: Relational alternatives to individualism (pp. 157-200). London: Ashgate.

Cooperrider, D.L. \& Sekerka, L.E. (2003). Toward a theory of positive organizational change. In K.S. Cameron, J.E. Dutton \& R.E. Quinn (Eds.), Positive organizational scholarship: Foundations of a new discipline (pp. 225-240). San Francisco: Berrett-Koehler.

Cooperrider, D.L. \& Whitney, D. (2003). Appreciative inquiry. In M. Gergen \& K.J. Gergen (Eds.), Social construction: A reader (pp. 174-181). London: Sage.

Cronbach, L.J. (1960). Essentials of psychological testing (2nd ed.). New York: Harper.

Denrell, J. (2005). Selection bias and the perils of benchmarking. Harvard Business Review, 83 (4, April), 114-119.

DDI Research and Insight (no date). Douglas W. Bray Ph.D. Retrieved 21 April 2005 from the Internet http://www.ddiworld.com/research/d_bray.asp.

Fiedler, F.E. (1967). A theory of leadership effectiveness. New York: McGraw-Hill.

Fourie, V., Woods, B. \& Bluen, S. (2005). Thriving on change: Building personal and organizational resilience at South African Breweries. Retrieved 19 March 2005 from the World Wide Web: http://www.fireglow.co.za/ss_sabreweries.htm.

Grid International (2004). Robert R. Blake. Retrieved 19 March 2005 from the World Wide Web: http://www.gridinternational. com/pdf/RRBlake.pdf.

Hall, C.S., Lindzey, G. \& Campbell, J.B. (1998). Theories of personality (4th ed.). New York: Wiley.

Hammer, M. \& Champy, J. (1993). Reengineering the corporation: A manifesto for business revolution. London: Brealey.

Herzberg, F, (1968). Work and the nature of man. London: Staples. 
Herzberg, F., Mausner, B. \& Snyderman, B. (1959). The motivation to work. New York: Wiley.

Keyfitz, N. (no date). Kenneth Ewart Boulding: January 18, 1910 - March 18, 1993. National Academy of Sciences: Biographical Memoirs. Retrieved 11 May 2005 from the World Wide Web: http://books.nap.edu/html/biomems/kboulding.html

Latham, G.P. \& Pinder, C.C. (2005). Work motivation theory and research at the dawn of the Twenty-first Century. Annual Review of Psychology, 56, 485-516.

Likert, R. (1961). New patterns of management. New York: McGraw-Hill.

Likert, R. (1967). The human organization: Its management and value. New York: McGraw-Hill.

Likert, R. \& Likert, J.G. (1976). New ways of managing conflict. New York: McGraw-Hill.

Ludema, J.D. (2001). From deficit discourse to vocabularies of hope: The power of appreciation. In D.L. Cooperrider, P.F. Sorenson, T.F. Yaeger \& D. Whitney (Eds.), Appreciative inquiry: An emerging direction for organization development. Champaign IL: Stipes Publishing. Retrieved 19 February 2004 from the World Wide Web: http://www.stipes.com.

Ludema, J.D., Wilmot, T.B. \& Srivastva, S. (1997). Organizational hope: Reaffirming the constructive task of social and organizational inquiry. Human Relations, 50, 1015-1052.

MacKinnon, D.W. (1978). In search of human effectiveness. Buffalo, NY: Creative Education Foundation.

Maslow, A.H. (1954). Motivation and personality. New York: Harper \& Row.

McClelland, D.C. (1961). The achieving society. New York: Free Press.

McClelland, D.C. (1975). Power: The inner experience. New York: Irvington.

McClelland, D.C. (1985). Human motivation. Glenview, IL: Scott, Foresman.

McClelland, D.C. \& Winter, D.G. (1969). Motivating economic achievement. New York: Free Press.

McGregor, D. (1960). The human side of enterprise. New York: McGraw-Hill.

McGraw-Hill/Dushkin (no date). Biography: David C. McClelland. Retrieved 20 March 2005 from the World Wide Web: http://www.dushkin.com/connectext/psy/ch09/bio9b.mhtml.

Mearns, J. (2004). The social learning theory of Julian B. Rotter. Retrieved 20 March 2005 from the World Wide Web: http://psych.fullerton.edu/jmearns/rotter.htm.

Murray, H.A. et al. (1962). Explorations in personality. New York: Science Editions. (Original work published in 1938)

Nunnally, J.C. \& Bernstein, I. (1994). Psychometric theory (3 ed.). New York: McGraw-Hill.

Office of Strategic Services Assessment Staff (1948). Assessment of men. New York: Rinehart.

Partington, A. (1992). The Oxford dictionary of quotations ( $4^{\text {th }}$ ed.). Oxford: Oxford University Press.

Reshef, Y. (2003, 16 September). Elton Mayo \& the human relations movement: 1880-1949. Retrieved 20 March 2005 from the World Wide Web: http://courses.bus.ualberta. ca/orga417.

Robbins, S.P. (2001). Organizational behavior (9th ed.). Upper Saddle River, NJ: Prentice Hall.

Rotter, J.B. (1966). Generalized expectancies for internal versus external control of reinforcement. Psychological Monographs, 80 (1, Whole No. 609).

Schein, E.H. (1969). Process consultation: Its role in organization development. Reading: MA: Addison-Wesley.

Schein, E.H. (1980). Organizational psychology (3rd ed.). Englewood Cliffs: Prentice-Hall.

Schein, E.H. (1985). Organizational culture and leadership. San Francisco: Jossey-Bass.

Schein, E.H. (1993). The academic as artist: Personal and professional roots. Retrieved 20 March 2005 from the World Wide Web: www.edschein.com.

Schepers, J.M. (1995). Locus of Control Inventory. Johannesburg: Author Publisher.

Steers. R.M., Mowday, R.T. \& Shapiro, D.L. (2004). Introduction to special topic forum: The future of work motivation theory. Academy of Management Review, 29, 379-387.

Strümpfer, D.J.W. (1993). Fie on "survival of the fittest": A more humane view of people in organizations. In N.C. Manganyi, H.C. Marais, K.F. Mauer \& R.J. Prinsloo (Eds.), A dissident among patriots (pp. 336-356). Pretoria: Centre for Science Development.

Strümpfer, D.J.W. (2005). Standing on shoulders of giants: Notes on early positive psychology (psychofortology). South African Journal of Psychology, 35, 21-45.

Strümpfer, D.J.W. (2006). The strengths perspective: Fortigenesis in adult life. Social Indicators Research, 77, 11-36.

The Management Thinkers (no date). Frederick Herzberg. Retrieved 20 March 2005 from the World Wide Web: http://www. managers.org.uk/institute /bookshop/manthk/thk-1.htm.

Thinkers 50 (2003). Edgar H. Schein. Retrieved 20 March 2005 from the World Wide Web: http://www.thinkers50.co.uk/? page $=$ biography\&ranking $=17$.

Van Vuuren, L.J. \& Crous, F. (2005). Utilising appreciative inquiry (AI) in creating a shared meaning of ethics in organisations. Journal of Business Ethics, 57, 399-412.

Wilson, E.O. (1998). Consilience: The unity of knowledge. London: Little, Brown.

Wissing, M.P., \& van Eeden, C. (1997, September). Psychological well-being: A fortigenic conceptualization and empirical clarification. Paper presented at Annual Congress of the Psychological Society of South Africa, Durban, South Africa.

Witzel, M. (Ed.) (2001a). Biographical dictionary of management: Fiedler, Fred Edward (1922-). Retrieved 21 March 2005 from the World Wide Web: http://www.thoemmes.com/.

Witzel, M. (Ed.) (2001b). Biographical dictionary of management: Likert, Rensis. Retrieved 21 March 2005 from the World Wide Web: http://www.thoemmes.com/dictionaries/bdm likert.htm. 